\title{
Time-dependent effect of trans-10,cis-12 conjugated linoleic acid on gene expression of lipogenic enzymes and regulators in mammary tissue of dairy cows
}

\author{
Kevin J. Harvatine,${ }^{* 1}$ Y. R. Boisclair, $†$ and Dale E. Bauman† \\ *Department of Animal Science, Penn State University, University Park 16802 \\ †Department of Animal Science, Cornell University, Ithaca, NY, 14853
}

\begin{abstract}
Trans-10,cis-12 conjugated linoleic acid (CLA) has been identified as an intermediate of rumen fatty acid biohydrogenation that caused milk fat depression (MFD) in the dairy cow. Previous studies in cows experiencing CLA- and diet-induced MFD have identified reduced mammary expression of the master lipogenic regulator sterol response element transcription factor 1 (SREBF1) and many of its dependent genes. To distinguish between primary mechanisms regulating milk fat synthesis and secondary adaptations to the reduction in milk fat, we conducted a time-course experiment. Eleven dairy cows received by abomasal infusion an initial priming dose of $6.25 \mathrm{~g}$ of CLA followed by $12.5 \mathrm{~g} / \mathrm{d}$ delivered in multiple pulses per day for $5 \mathrm{~d}$. Cows were milked $3 \times / \mathrm{d}$ and mammary biopsies were obtained under basal condition (prebolus control) and 12, 30, and $120 \mathrm{~h}$ relative to initiation of CLA infusion. Milk fat concentration and yield decreased progressively reaching a nadir at $69 \mathrm{~h}(1.82 \%$ and $38.2 \mathrm{~g} / \mathrm{h})$ and averaged $2.03 \pm 0.19 \%$ and $42.1 \pm 4.10 \mathrm{~g} / \mathrm{h}$ on the last day of treatment $( \pm$ standard deviation). Expression of fatty acid synthase $(F A S N)$ and lipoprotein lipase $(L P L)$ were decreased at 30 and $120 \mathrm{~h}$ compared with control. Expression of SREBF1 and THRSP were also decreased at 30 and $120 \mathrm{~h}$ compared with control. Additionally, we failed to observe changes in other factors, including peroxisome proliferator-activated receptor $\gamma$ and liver $\mathrm{x}$ receptor $\beta$ and milk fat globular membrane proteins, during CLA treatment. However, expression of milk fat globular membrane proteins were decreased after $14 \mathrm{~d}$ of diet-induced MFD in samples from a previous experiment, indicating a possible long-term response. The rapid decrease in lipogenic enzymes, $S R E B F 1$, and
\end{abstract}

Received October 3, 2017.

Accepted March 20, 2018.

${ }^{1}$ Corresponding author: kjh182@psu.edu
THRSP provide strong support for their transcriptional regulation as a primary mechanism of milk fat depression.

Key words: milk fat, conjugated linoleic acid, SREBF1, THRSP, milk fat depression

\section{INTRODUCTION}

Milk fat synthesis is variable in dairy cows and responsive to nutritional factors. Specifically, diet-induced milk fat depression (MFD) represents a decrease in milk fat yield with no change in yield of milk or other milk components (see review by Bauman and Griinari, 2003). Milk fat depression is caused by unique intermediates from ruminal fatty acid (FA) biohydrogenation; trans-10, cis-12 CLA was the first of these unique biohydrogenation intermediates to be identified and is the most well studied (Baumgard et al., 2000).

During MFD, mammary lipogenic capacity is decreased and transcription of mammary genes involved in milk fat synthesis are coordinately downregulated (Baumgard et al., 2002). Decreased expression of sterol response element transcription factor 1 ( SREBF1) and thyroid hormone responsive spot 14 (THRSP) have been reported during trans-10,cis-12 CLA and dietinduced MFD (Harvatine and Bauman, 2006a). The protein SREBF1 is a master regulator of lipid synthesis and has been shown to be repressed by PUFA in liver of rodents and humans (Jump et al., 2005). Although its exact biochemical function is not known, spot 14 (THRPS) is nuclear protein that is closely associated with the regulation of FA synthesis in lipogenic tissues, including the mammary gland during MFD, and may function as a transcriptional co-activator (Cunningham et al., 1998; Chou et al., 2007, 2008). Additionally, studies performed in mammary epithelial cells have suggested roles for liver x receptor $\beta$ ( LXRB; Oppi-Williams et al., 2013; Harvatine et al., 2014) and peroxisome proliferator-activated receptor $\gamma(\mathbf{P P A R} \gamma$; Shi et al., 2014) in regulation of milk fat synthesis (reviewed by Bionaz et al., 2015). 
Virtually all previous gene expression studies have been performed in the context of fully established MFD and, accordingly, cannot distinguish causative mechanisms from secondary physiological adaptations to reduced milk fat synthesis (i.e., responses causing reduced lipogenesis vs. those only associated with reduced mammary lipogenesis). Our objective was to investigate the temporal expression of lipogenic enzymes, SREBF1, and THRSP in mammary tissue of lactating cows during CLA-induced MFD and our hypothesis was that SREBF1 and THRSP are primary responses during induction of MFD.

\section{MATERIALS AND METHODS}

\section{Animals and Treatments}

All experimental procedures were approved by the Cornell University Institutional Animal Care and Use Committee. Samples were collected from 11 ruminally fistulated lactating dairy cows from the Cornell University Teaching and Research Center in 2 blocks. In the first block, 8 midlactation cows were assigned randomly to sampling sequence in a 2-period design. Mammary biopsies before the CLA bolus (CON) and $12 \mathrm{~h}$ after the abomasal CLA bolus infusion were collected during 1 period and mammary biopsies were collected 30 and $120 \mathrm{~h}$ after the bolus in the other period. Biopsies within period were taken from alternate rear quarters and periods were separated by $14 \mathrm{~d}$ to allow recovery. In the second block, 3 midlactation cows had biopsies collected sequentially from alternate rear quarters in a single period, with biopsies of the same quarter being at least $4 \mathrm{~d}$ apart.

Trans-10, cis-12 CLA was infused into the abomasum using a $0.5-\mathrm{cm}$ i.d. line placed through the rumen cannula. An initial priming dose of $6.25 \mathrm{~g}$ of CLA was given at time zero, followed by $2.1 \mathrm{~g}$ every $4 \mathrm{~h}$ for 36 $\mathrm{h}$ and then $3.1 \mathrm{~g}$ every $6 \mathrm{~h}$ until $120 \mathrm{~h}$. This provided $12.5 \mathrm{~g} / \mathrm{d}$ of trans-10,cis-12 CLA, which is slightly over the maximally effective dose $(\sim 10 \mathrm{~g} / \mathrm{d}$; de Veth et al., 2004). The trans-10,cis-12 CLA methyl ester stock (BASF Corporation, Ludwigshafen, Germany) contained $88.3 \%$ total CLA (98\% trans-10,cis-12 isomer), $6.8 \%$ palmitic acid, $2.7 \%$ oleic acid, and $2.0 \%$ stearic acid. Previous investigations have shown that the methyl ester and free FA forms of trans-10, cis-12 CLA are equally effective in inhibiting milk fat synthesis (de Veth et al., 2004).

Cows received a TMR fed once per day in the first block and twice per day in the second block. Feed ingredients were dried $\left(55^{\circ} \mathrm{C}\right.$ forced-air oven for 72 h), ground (Wiley mill with 1-mm screen; Arthur H.
Thomas, Swedesboro, NJ), and nutrient composition determined by wet chemistry procedures (AOCS, 2000; at Dairy One Cooperative, Ithaca, NY). The diet contained 31.1 and $33.2 \% \mathrm{NDF}$ and 16.6 and $16.7 \% \mathrm{CP}$ in the first and second block, respectively (Supplemental Table S1; https://doi.org/10.3168/jds.2017-13935).

Samples from a previous experiment (Harvatine and Bauman, 2006a) were used to further investigate the regulation of the milk fat globular membrane (MFGM) proteins during MFD. Briefly, mammary biopsies were collected as described above from control (normal milk fat) and after $3 \mathrm{~d}$ of intravenous infusion of $10 \mathrm{~g} / \mathrm{d}$ of trans-10, cis-12 CLA that resulted in a $24 \%$ decrease in milk fat yield, and $10 \mathrm{~d}$ of a low-forage and high-oil diet $(3.0 \%$ soybean oil and $1.5 \%$ fish oil $)$ that resulted in a $38 \%$ reduction in milk fat yield.

\section{Sampling and Analysis}

Cows were milked $3 \times / \mathrm{d}$ (0800, 1600, and $2400 \mathrm{~h}$ ) and samples were taken at times shown and analyzed for fat and true protein using a mid-infrared spectrophotometer (AOCS, 2000; at Dairy One Cooperative). Additionally, milk lipids were extracted in hexaneisopropanol, transmethylated with sodium methoxide, and FAME were quantified by GC according to Perfield et al. (2006). Transfer of CLA to milk was calculated as yield in milk divided by amount infused.

Mammary biopsies were performed at approximately $1030 \mathrm{~h}$ according to (Harvatine and Bauman, 2006a) using a needle biopsy tool (Magnum Biopsy Gun system; Bard Biopsy Systems, Tempe, AZ). Tissues were snapfrozen in liquid nitrogen and stored at $-80^{\circ} \mathrm{C}$. Total RNA was isolated from approximately $30 \mathrm{mg}$ of mammary tissue using the RNeasy Lipid Kit with on column Dnase I (Qiagen, Valencia, CA). The RNA concentration and integrity were determined by an Agilent 2100 BioAnalyzer [RNA integrity number $8.4 \pm 0.46$ (mean \pm SD); Agilent Technologies, Santa Clara, CA]. Total RNA was reverse transcribed using the SuperScript III First Strand Synthesis kit (Invitrogen, Carlsbad, CA) with random primers $(3 \mu \mathrm{g}$ of total RNA in a $20 \mu \mathrm{L}$ total reaction with $2.5 \mathrm{ng} / \mu \mathrm{L}$ of primers). Quantitative real-time reverse transcriptase PCR (qRT-PCR) assays were developed and validated for genes of interest (Supplemental Table S2; https://doi.org/10.3168/jds .2017-13935), as described by Harvatine and Bauman (2006a). The qRT-PCR reactions included ABI Power SYBR with ROX (Applied Biosystems, Foster City, CA), $400 \mathrm{n} M$ gene-specific forward and reverse primers (Invitrogen), and 5 to $25 \mathrm{ng}$ of cDNA in a 2-step amplification program $\left(95^{\circ} \mathrm{C}\right.$ for $15 \mathrm{~s}$ and $60^{\circ} \mathrm{C}$ for $\left.60 \mathrm{~s}\right)$ with an ABI PRISM 7000 Sequence Detection System 
(Applied Biosystems). Dissociation curves were generated at the end of amplification to verify presence of a single product. Sample message level was determined relative to a dilution curve of pooled mammary cDNA (ABI Prism, 2001).

The mammary samples from (Harvatine and Bauman, 2006a) were handled similarly as described above and qRT-PCR was used to determined expression of $C D 36$ molecule (CD36), butyrophilin subfamily 1 member A1 (BTN1), perilipin 2 (PLIN2; previously called adipophilin), xanthine dehydrogenase $(X D H$; commonly called xanthine oxidoreductase), and mucin 1 (MUC1).

\section{Statistical Analysis}

Data from the time course experiment were analyzed using the fit model procedure of JMP Pro (SAS Institute Inc., Cary, NC). The model to test treatment means included the random effect of cow and period and the fixed effect of time after the CLA priming dose. Additionally, the geometric mean of 3 reference genes [ribosomal protein S9 (RPS9), $\beta$-actin $(A C T B)$, and $\beta 2$-microglobulin (B2M)] was calculated using GeNorm (Vandesompele et al., 2002) and used as a covariant in the model (Allison et al., 1995; Martinez et al., 2004). Data were log-transformed when necessary, and backtransformed data are reported. Means and standard errors were scaled with control scaled to equal 100 after statistical analysis. Preplanned contrasts compared gene expression of CON versus $12 \mathrm{~h}$, CON versus 30 $\mathrm{h}$, and CON versus $120 \mathrm{~h}$. Expression of the MFGM proteins in the samples from Harvatine and Bauman (2006a) were similarly modeled with the effect of treatment rather than time after bolus, and preplanned contrast was control versus CLA and control versus low-forage and high-oil diet.

\section{RESULTS AND DISCUSSION}

\section{Milk trans-10,cis-12 CLA and Milk Fat Synthesis}

Milk fat concentration of trans-10,cis-12 CLA was $0.25 \%$ of total FA at $13 \mathrm{~h}$ after the bolus and averaged $0.28 \pm 0.021 \%( \pm \mathrm{SD})$ from 29 to $117 \mathrm{~h}$ after the bolus (Figure 1A). Transfer efficiency over the last day of treatment was $22.9 \%(2.8 \mathrm{~g} / \mathrm{d}$ transferred $)$, which is similar to the $21.8 \%$ transfer efficiency $(2.7 \mathrm{~g} / \mathrm{d}$ transferred) predicted by the meta-regression of de Veth et al. (2004).

Milk fat concentration and yield decreased progressively and was lower than control by $21 \mathrm{~h}$ after the bolus (Figure 1C and D). A nadir was observed in milk fat concentration and yield at $69 \mathrm{~h}(1.82 \%$ and $38.2 \mathrm{~g} / \mathrm{h}$, respectively) and averaged $2.03 \pm 0.19 \%$ and $42.1 \pm$
$4.10 \mathrm{~g} / \mathrm{h}$ on the last day of treatment, respectively. This represented a $40 \%$ reduction in milk fat concentration and a $46 \%$ reduction in milk fat yield. This reduction is very similar to previous work, as the summary by de Veth et al. (2004) predicts the $12.5-\mathrm{g} / \mathrm{d}$ dose would decrease milk fat yield by $47 \%$.

The response to CLA occurred in 2 phases and varied according to the origin of the FA (Figure 1B). The concentration of preformed FA ( $>16 \mathrm{C}$ ) was $38.9 \%$ of FA before the time-zero bolus and first increased to 40.9 $\pm 0.35 \%$ FA between 13 and $29 \mathrm{~h}$ and then further increased to $46.3 \pm 0.46 \%$ of FA after $69 \mathrm{~h}$ on treatment. De novo-synthesized FA tended to be decreased at 21 $\mathrm{h}$ and were decreased 5.4 percentage points after $69 \mathrm{~h}$ compared with before the bolus. Fatty acids of mixed origin (16 C) were $30.9 \%$ before the time-zero bolus and initially decreased to $29.5 \pm 0.03 \%$ of FA from 13 to 29 $\mathrm{h}$ and then decreased to $28.6 \pm 0.64 \%$ of FA after $69 \mathrm{~h}$. We had previously observed a similar 2-phase response with the same CLA infusion protocol during every 4-h milking and proposed that the first phase is a decrease in both de novo and preformed FA, whereas the second phase is a greater reduction in de novo synthesis (Harvatine and Bauman, 2011). The timing of the biopsies $(12,30$, and $120 \mathrm{~h})$ was selected to provide tissue during critical points during these phases. Yield of all categories of FA were decreased by $13 \mathrm{~h}$ after initiation of CLA infusion (Supplemental Figure S1; https://doi .org/10.3168/jds.2017-13935).

\section{Milk Fat Synthesis and Expression of Lipogenic Enzymes}

Mammary expression of FASN and $L P L$ were decreased over $30 \%$ at $30 \mathrm{~h}$ after the bolus, but expression of SCD1 was not changed (Figure 2A). These genes are transcriptionally regulated and were selected to characterize the effect on de novo synthesis, preformed FA pathways, and FA desaturation, respectively ( $\mathrm{Sul}$ and Wang, 1998; Mauvoisin and Mounier, 2011; Kersten, 2014). A coordinated downregulation of lipogenic enzymes, including FASN and $L P L$, was consistently observed in mammary tissue when CLA and diet-induced MFD plateaued (Harvatine and Bauman, 2006a). Vyas et al. (2013) also reported decreased protein abundance of FASN and acetyl-CoA synthase in mammary tissue during CLA treatment. Although the delta-9 desaturase ratio (product-precursor relationship) consistently decreased during CLA-induced MFD, SCD1 expression is variable; Harvatine and Bauman (2006a) reported no change, whereas Gervais et al. (2009) reported a tendency to decrease and Han et al. (2012) reported a decrease in $S C D 1$ expression during CLA-induced MFD. The rapid decrease in lipogenic enzymes provides 
additional support for a strong role of transcriptional regulation during MFD.

\section{Expression of SREBF1 and THRSP}

Mammary expression of SREBF1 was decreased $31 \%$ at $30 \mathrm{~h}$ and $48 \%$ at $120 \mathrm{~h}$ after the time-zero bolus (Figure 2B). Protein SREBF1 is a master regulator of lipid synthesis, and one key point of its regulation is protein cleavage resulting in the transcriptionally active nuclear fragment (Jump et al., 2005). However, active SREBF1 positively regulates its own regulation, making SREBF1 expression indicative of SREBF1 activity (Jump et al., 2005). Decreased abundance of the active nuclear fragment was originally reported by Peterson et al. (2004) in mammary cell culture, and transcriptional downregulation of $S R E B F 1$ in vivo was reported by Harvatine and Bauman (2006a) and subsequently verified by others (e.g., Gervais et al., 2009; Han et al., 2012; Vyas et al., 2013). Li et al. (2014) reported that overexpression of SREBF1 increased milk fat and inhibition decreased milk fat in bovine mammary epithelial cell culture and $\mathrm{Ma}$ et al. (2014) reported that trans-10, cis-12 CLA inhibited a reporter construct that contained the SREBP response element.

Mammary expression of THRSP was also decreased over $41 \%$ at 30 and $120 \mathrm{~h}$ after the bolus compared with control (Figure 2B). Originally THRSP was identified as a CLA-responsive gene in bovine mammary epithelial cell culture (Peterson et al., 2004) and was later reported to be repressed in the mammary gland during diet and CLA-induced MFD (Harvatine and Bauman, 2006a). Overexpression of THRSP was reported to increase fat synthesis in bovine mammary epithelial cells (Cui et al., 2015).

The protein PPARGC1 $\alpha$ is a transcriptional co-activator that was not changed by CLA, but was decreased by $14 \mathrm{~d}$ of diet-induced MFD (Harvatine and Bauman,
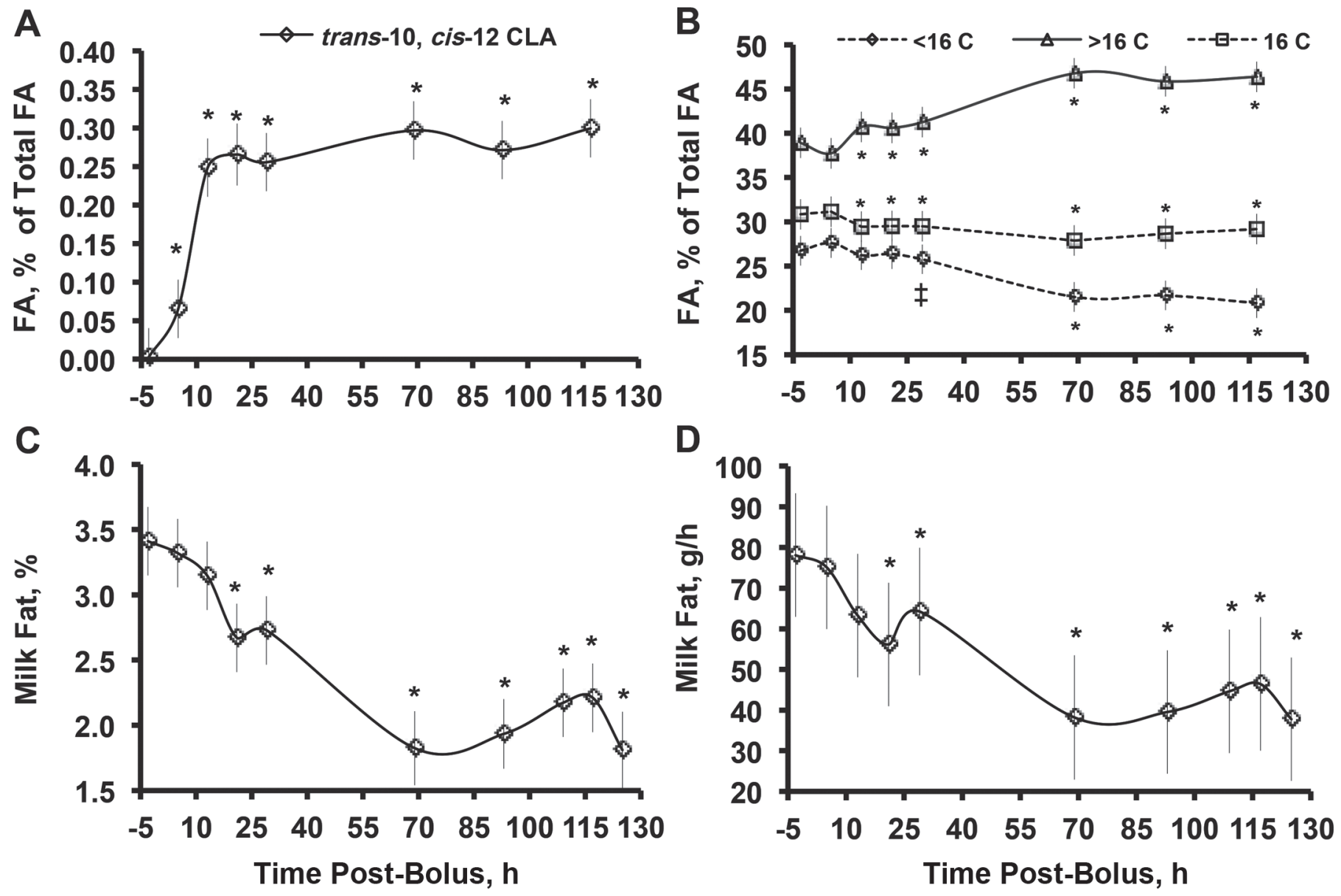

Figure 1. Temporal response of milk fat and milk fatty acid (FA) profile during abomasal infusion of $12.5 \mathrm{~g} / \mathrm{d}$ of trans-10,cis-12 CLA for 5 d. (A) Concentration of trans-10, cis-12 CLA in milk fat; (B) concentration of FA less than 16 carbons $(<16 \mathrm{C}), 16 \mathrm{C}$, and $>16 \mathrm{C}$ in milk fat; (C) milk fat concentration; and (D) milk fat yield. Values are LSM \pm SEM. *Asterisks indicate difference from prebolus level $(P<0.05)$. $\ddagger$ indicates a tendency $(P<0.10)$. 

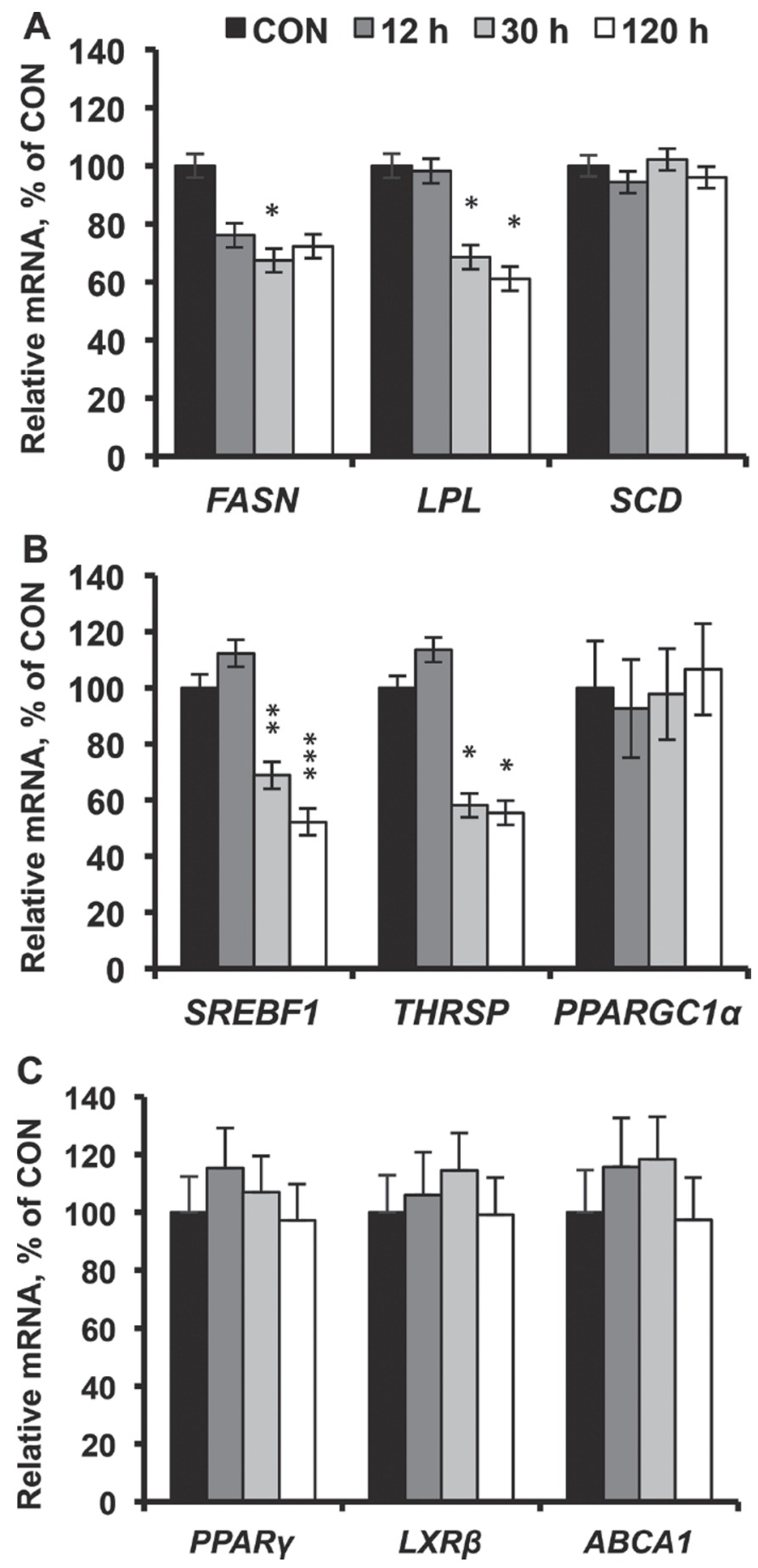

Figure 2. Temporal expression of genes in the mammary gland during abomasal infusion of $12.5 \mathrm{~g} / \mathrm{d}$ of trans-10, cis-12 CLA for $5 \mathrm{~d}$ [before infusion, control (CON), and 12, 30, and $120 \mathrm{~h}$ after infusion]. (A) Selected lipogenic enzymes including fatty acid synthase $(F A S N)$, lipoprotein lipase $(L P L)$, and stearoyl CoA desaturase $(S C D 1)$; (B) expression of sterol response element binding protein 1 (SREBF1), thyroid hormone responsive spot 14 (THRSP), and peroxisome proliferative activated receptor gamma coactivator $1 \alpha(P P A R G C 1 \alpha) ;(\mathrm{C})$ expression of peroxisome proliferator-activated receptor $\gamma(P P A R \gamma)$, liver $\mathrm{x}$ receptor $\beta(L X R B)$, and ATP binding cassette subfamily A member $1(A B C A 1)$. Values are LSM \pm SEM $(\mathrm{n}=11)$. Asterisks indicate difference from control $\left({ }^{*} P<0.05,{ }^{* *} P<0.01,{ }^{* * *} P<0.001\right)$.

2006b). Mammary expression of PPARGC1A was not changed by CLA treatment it the current experiment, indicating it may either be responsive to other bioactive FA produced during diet-induced MFD or to longer durations of MFD.

Functional roles for both SREBF1 and THRSP have been reported in transgenic mouse models and bovine mammary cell culture. Mammary disruption of SCAP, which is required for SREBF1 activation, decreases pup growth and milk fat concentration (Rudolph et al., 2010), and whole body disruption of THRSP decreases milk fat concentration approximately 50\% (Zhu et al., 2005 ). Demonstrating functional roles of genes in vivo is difficult in the cow, as transgenic models are not feasible and cell culture models do not recapitulate lactation because they fail to export synthesized lipids (Collier et al., 1977); however, improved 3-dimensional culture models may resolve some of these issues (Campbell and Watson, 2009). The decreased expression of $S R E B F 1$ at $30 \mathrm{~h}$ in the current experiment indicates it is an early phase response.

A key question that remains is the mechanism linking CLA and downregulation of SREBF1 and THRSP as neither protein has ligand binding domains. Lee et al. (2010) identified Ubxd8 as an ER associated sensor protein that changed confirmation in the presence of UFA and resulted in increased proteolysis of INSIG1, but the interaction of CLA with UBXD8 is not known. SREBF1 regulation is thought to be dependent on membrane composition, especially in response to sterol concentration (Hagen et al., 2010).

\section{Expression of PPARY and LXRB and Target Genes}

Members of the nuclear hormone receptor family could be regulators of lipid synthesis in the mammary gland and regulated by CLA, as they have ligandbinding pockets and are predominantly regulated by ligand activation. Although liver $\mathrm{x}$ receptor $(\mathbf{L X R})$ agonists increase lipid synthesis in mammary epithelial cells, Harvatine et al. (2014) reported that neither LXR isoform or their specific target genes were modified during CLA or diet-induced MFD. No effect of CLA on $L X R B$ or ATP-binding cassette subfamily A member 1 ( $A B C A 1)$, a target gene highly regulated by LXR activation, was observed in the current experiment. An early investigation of CLA in other models proposed a role of modification of PPAR $\gamma$ signaling ( $\mathrm{Yu}$ et al., 2002). A role of PPAR $\gamma$ in mammary regulation of lipid synthesis has been proposed (Bionaz and Loor, 2008). In the current experiment, PPAR $\gamma$ was not modified by CLA. Interestingly, in rodent models, PPAR $\gamma$ was activated by trans-10,cis-12 CLA in a transactivation assay, but cis-9,trans-11 CLA, which does not cause 
milk fat depression, also activated PPAR $\gamma$ (Moya-Camarena et al., 1999; Yu et al., 2002). Ma et al. (2014) also reported that trans-10, cis-12 CLA did not inhibit
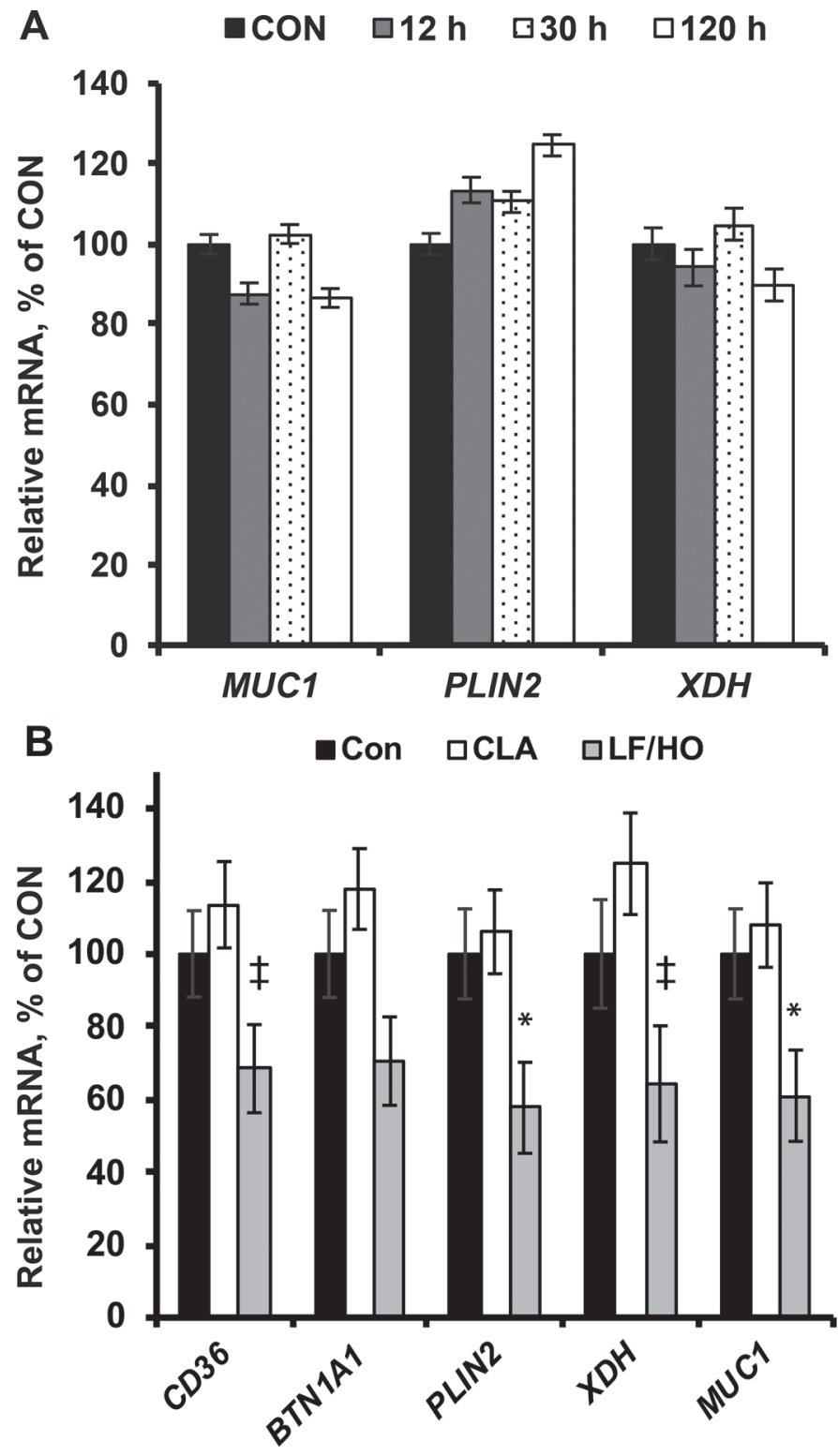

Figure 3. Expression of milk fat globular membrane proteins during milk fat depression in 2 experiments. (A) Temporal expression of mucin 1 (MUC1), perilipin 2 (PLIN2, also known as adipophilin), and xanthine dehydrogenase $(X D H$, commonly called xanthine oxidoreducatase) in mammary tissue during abomasal infusion of $12.5 \mathrm{~g} / \mathrm{d}$ of trans-10,cis-12 CLA for $5 \mathrm{~d}$ [before infusion, control (CON), and 12, 30, and $120 \mathrm{~h}$ after infusion]. (B) Expression of CD36 molecule (CD36), butyrophilin subfamily 1 member A1 (BTN1A1), PLIN2, $X D H$, and $M U C 1$ during control (CON), 3-d intravenous infusion of 10 $\mathrm{g} / \mathrm{d}$ of trans-10,cis-12 CLA that resulted in a $24 \%$ decrease in milk fat, and $14 \mathrm{~d}$ of a low-forage and high-oil diet (LF/HO; $3.0 \%$ soybean oil and $1.5 \%$ fish oil) that resulted in a $24 \%$ decrease in milk fat. Values are LSM \pm SEM. Differences compared with control are indicated $(\ddagger P$ $\left.<0.10,{ }^{*} P<0.05\right)$. activation of promoters with PPAR and LXR response elements in mammary epithelial cells.

\section{Expression of Milk Fat Globular Membrane Proteins}

Milk fat is assembled into lipid droplets and surrounded by phospholipids and specific proteins that form the MFGM and are essential for the fat secretion form the mammary epithelial cell (Bauman et al., 2006; Cavaletto et al., 2008). Expression of the MFGM genes has been generally overlooked in investigation of MFD. As they are essential, it is possible that a specific downregulation would result in a limitation of milk fat secretion and an inhibition of fat synthesis. We determined the expression of MUC1, PLIN2, and $X D H$ in the current study (Figure 3), as they are highly abundant in the MFGM and are thought to have essential roles in lipid secretion (Mather et al., 2001; Ogg et al., 2004; McManaman, 2012); however, their expression was not changed at any time point. To expand our investigation of the MFGM, we examined expression in mammary samples from Harvatine and Bauman (2006a), who investigated MFD induced by a 3-d i.v. treatment of CLA or feeding a low-forage and high-oil diet for 14 d. Similarly, we found no effect of CLA on the MFGM genes, including CD36, BTN1A1, PLIN2, XDH, and $M U C 1$. However, diet-induced MFD decreased expression of PLIN2 and MUC1 and tended to decrease CD36 and $X D H$. The reduction during diet-induced MFD may be related to other ruminally produced bioactive isomers or to the longer duration of MFD (14 d for diet-induced MFD vs. 3 and $5 \mathrm{~d}$ for CLA treatments). In either case, a reduction in MFGM is not required for induction of MFD and is expected to be a secondary long-term adaptation to reduced milk fat yield if it does occur.

\section{CONCLUSIONS}

The rapid decrease in lipogenic enzymes, SREBF1, and THRSP during CLA-induced MFD provides strong support for transcriptional regulation of these genes being a primary mechanism of MFD. Roles for the nuclear hormone receptors PPARY and $L X R B$ and milk fat globular membrane proteins in CLA-induced MFD was not observed.

\section{ACKNOWLEDGMENTS}

The authors thank Debra Dwyer, Stephanie Wesolowski, James Perfield, II, Antonio Garcia, Euridice Castañeda-Gutiérrez, Bruce Berggren-Thomas, and the staff of the Cornell University Dairy Teaching and Research Center for their assistance in this experiment. 
In addition, we thank Patricia A. Johnson (Cornell University, Ithaca, NY) for assistance with the qRT PCR analyses, and BASF (Ludwigshafen, Germany) for providing the purified trans-10,cis-12 CLA. Research supported in part by National Research Initiative Competitive Grants Program, Cooperative State Research, Education, and Extension Service, USDA (grant \#2006-35206-16643; PI DEB), Agriculture and Food Research Initiative Competitive Grant no. 201065206-20723 from the USDA National Institute of Food and Agriculture (PI KJH, Washington, DC), and by the Cornell Agricultural Experiment Station (Ithaca, NY).

\section{REFERENCES}

Allison, D. B., F. Paultre, M. I. Goran, E. T. Poehlman, and S. B. Heymsfield. 1995. Statistical considerations regarding the use of ratios to adjust data. Int. J. Obes. Relat. Metab. Disord. 19:644652 .

AOCS. 2000. Official Methods of Analysis. 17th ed. AOCS, Arlington, VA.

Bauman, D. E., and J. M. Griinari. 2003. Nutritional regulation of milk fat synthesis. Annu. Rev. Nutr. 23:203-227.

Bauman, D. E., I. H. Mather, R. J. Wall, and A. L. Lock. 2006. Major advances associated with the biosynthesis of milk. J. Dairy Sci. 89:1235-1243.

Baumgard, L. H., B. A. Corl, D. A. Dwyer, A. Saebo, and D. E. Bauman. 2000. Identification of the conjugated linoleic acid isomer that inhibits milk fat synthesis. Am. J. Physiol. Regul. Integr. Comp. Physiol. 278:R179-R184.

Baumgard, L. H., E. Matitashvili, B. A. Corl, D. A. Dwyer, and D. E. Bauman. 2002. Trans-10, cis-12 conjugated linoleic acid decreases lipogenic rates and expression of genes involved in milk lipid synthesis in dairy cows. J. Dairy Sci. 85:2155-2163.

Bionaz, M., and J. J. Loor. 2008. Gene networks driving bovine milk fat synthesis during the lactation cycle. BMC Genomics 9:366.

Bionaz, M., J. Osorio, and J. J. Loor. 2015. Triennial lactation symposium: Nutrigenomics in dairy cows: Nutrients, transcription factors, and techniques. J. Anim. Sci. 93:5531-5553.

Campbell, J. J., and C. J. Watson. 2009. Three-dimensional culture models of mammary gland. Organogenesis 5:43-49.

Cavaletto, M., M. G. Giuffrida, and A. Conti. 2008. Milk fat globule membrane components-a proteomic approach. Adv. Exp. Med. Biol. 606:129-141.

Chou, W. Y., Y. S. Cheng, C. L. Ho, S. T. Liu, P. Y. Liu, C. C. Kuo, H. P. Chang, Y. H. Chen, G. G. Chang, and S. M. Huang. 2007. Human spot 14 protein interacts physically and functionally with the thyroid receptor. Biochem. Biophys. Res. Commun. 357:133-138

Chou, W. Y., C. L. Ho, M. L. Tseng, S. T. Liu, L. C. Yen, and S. M. Huang. 2008. Human spot 14 protein is a p53-dependent transcriptional coactivator via the recruitment of thyroid receptor and zac1. Int. J. Biochem. Cell Biol. 40:1826-1834.

Collier, R. J., D. E. Bauman, and R. L. Hays. 1977. Lactogenesis in explant cultures of mammary tissue from pregnant cows. Endocrinology 100:1192-1200.

Cui, Y., Z. Liu, X. Sun, X. Hou, B. Qu, F. Zhao, X. Gao, Z. Sun, and Q. Li. 2015. Thyroid hormone responsive protein spot 14 enhances lipogenesis in bovine mammary epithelial cells. In Vitro Cell. Dev. Biol. Anim. 51:586-594. https://doi.org/10.1007/s11626-014-9865 -8 .

Cunningham, B. A., J. T. Moncur, J. T. Huntington, and W. B. Kinlaw. 1998. "Spot 14" protein: A metabolic integrator in normal and neoplastic cells. Thyroid 8:815-825. de Veth, M. J., J. M. Griinari, A. M. Pfeiffer, and D. E. Bauman. 2004. Effect of CLA on milk fat synthesis in dairy cows: Comparison of inhibition by methyl esters and free fatty acids, and relationships among studies. Lipids 39:365-372.

Gervais, R., J. W. McFadden, A. J. Lengi, B. A. Corl, and P. Y. Chouinard. 2009. Effects of intravenous infusion of trans-10, cis-12 18:2 on mammary lipid metabolism in lactating dairy cows. J. Dairy Sci. 92:5167-5177.

Hagen, R. M., S. Rodriguez-Cuenca, and A. Vidal-Puig. 2010. An allostatic control of membrane lipid composition by srebp1. FEBS Lett. 584:2689-2698.

Han, L. Q., K. Pang, H. J. Li, S. B. Zhu, L. F. Wang, Y. B. Wang, G. Q. Yang, and G. Y. Yang. 2012. Conjugated linoleic acid-induced milk fat reduction associated with depressed expression of lipogenic genes in lactating Holstein mammary glands. Genet. Mol. Res. 11:4754-4764.

Harvatine, K. J., and D. E. Bauman. 2006a. Srebp1 and thyroid hormone responsive spot 14 (s14) are involved in the regulation of bovine mammary lipid synthesis during diet-induced milk fat depression and treatment with cla. J. Nutr. 136:2468-2474.

Harvatine, K. J., and D. E. Bauman. 2006b. Srebp1 and thyroid hormone responsive spot 14 (s14) are involved in the regulation of bovine mammary lipid synthesis during diet-induced milk fat depression and treatment with CLA. J. Nutr. 136:2468-2474.

Harvatine, K. J., and D. E. Bauman. 2011. Characterization of the acute lactational response to trans-10, cis-12 conjugated linoleic acid. J. Dairy Sci. 94:6047-6056.

Harvatine, K. J., Y. R. Boisclair, and D. E. Bauman. 2014. Liver x receptors stimulate lipogenesis in bovine mammary epithelial cell culture but do not appear to be involved in diet-induced milk fat depression in cows. Physiol. Rep. 2:e00266.

Jump, D. B., D. Botolin, Y. Wang, J. Xu, B. Christian, and O. Demeure. 2005. Fatty acid regulation of hepatic gene transcription. J. Nutr. 135:2503-2506.

Kersten, S. 2014. Physiological regulation of lipoprotein lipase. Biochim. Biophys. Acta 1841:919-933.

Lee, J. N., H. Kim, H. Yao, Y. Chen, K. Weng, and J. Ye. 2010. Identification of ubxd8 protein as a sensor for unsaturated fatty acids and regulator of triglyceride synthesis. Proc. Natl. Acad. Sci. USA 107:21424-21429.

Li, N., F. Zhao, C. Wei, M. Liang, N. Zhang, C. Wang, Q. Z. Li, and X. J. Gao. 2014. Function of srebp1 in the milk fat synthesis of dairy cow mammary epithelial cells. Int. J. Mol. Sci. 15:16998-17013.

Ma, L., A. J. Lengi, M. L. McGilliard, D. E. Bauman, and B. A. Corl 2014. Short communication: Effect of trans-10,cis-12 conjugated linoleic acid on activation of lipogenic transcription factors in bovine mammary epithelial cells. J. Dairy Sci. 97:5001-5006.

Martinez, M. M., G. M. Hill, J. E. Link, N. E. Raney, R. J. Tempelman, and C. W. Ernst. 2004. Pharmacological zinc and phytase supplementation enhance metallothionein mRNA abundance and protein concentration in newly weaned pigs. J. Nutr. 134:538-544.

Mather, I. H., L. J. Jack, P. J. Madara, and V. G. Johnson. 2001. The distribution of muc1, an apical membrane glycoprotein, in mammary epithelial cells at the resolution of the electron microscope: Implications for the mechanism of milk secretion. Cell Tissue Res. 304:91-101.

Mauvoisin, D., and C. Mounier. 2011. Hormonal and nutritional regulation of scd1 gene expression. Biochimie 93:78-86.

McManaman, J. L. 2012. Milk lipid secretion: Recent biomolecular aspects. Biomol. Concepts 3:581-591.

Moya-Camarena, S. Y., J. P. Vanden Heuvel, S. G. Blanchard, L. A. Leesnitzer, and M. A. Belury. 1999. Conjugated linoleic acid is a potent naturally occurring ligand and activator of pparalpha. J. Lipid Res. 40:1426-1433.

Ogg, S. L., A. K. Weldon, L. Dobbie, A. J. Smith, and I. H. Mather. 2004. Expression of butyrophilin (btn1a1) in lactating mammary gland is essential for the regulated secretion of milk-lipid droplets. Proc. Natl. Acad. Sci. USA 101:10084-10089.

Oppi-Williams, C., J. K. Suagee, and B. A. Corl. 2013. Regulation of lipid synthesis by liver $\mathrm{x}$ receptor alpha and sterol regulatory 
element-binding protein 1 in mammary epithelial cells. J. Dairy Sci. 96:112-121.

Perfield, J. W. II, P. Delmonte, A. L. Lock, M. P. Yurawecz, and D. E. Bauman. 2006. Trans-10, trans-12 conjugated linoleic acid does not affect milk fat yield but reduces delta9-desaturase index in dairy cows. J. Dairy Sci. 89:2559-2566.

Peterson, D. G., E. A. Matitashvili, and D. E. Bauman. 2004. The inhibitory effect of trans-10, cis-12 cla on lipid synthesis in bovine mammary epithelial cells involves reduced proteolytic activation of the transcription factor srebp-1. J. Nutr. 134:2523-2527.

Prism, A. B. I. 2001. Relative quantification of gene expression. 7700 sequence detection system user bulletin 2. Pages 1-36. Applied Biosystems, Foster City, CA.

Rudolph, M. C., J. Monks, V. Burns, M. Phistry, R. Marians, M. R. Foote, D. E. Bauman, S. M. Anderson, and M. C. Neville. 2010. Sterol regulatory element binding protein (srebf-1) and dietary lipid regulation of fatty acid synthesis in the mammary epithelium. Am. J. Physiol. Endocrinol. Metab. 299:E918-E927.

Shi, H. B., W. S. Zhao, J. Luo, D. W. Yao, Y. T. Sun, J. Li, H. P. Shi, and J. J. Loor. 2014. Peroxisome proliferator-activated receptor gamma1 and gamma2 isoforms alter lipogenic gene networks in goat mammary epithelial cells to different extents. J. Dairy Sci. 97:5437-5447.
Sul, H. S., and D. Wang. 1998. Nutritional and hormonal regulation of enzymes in fat synthesis: Studies of fatty acid synthase and mitochondrial glycerol-3-phosphate acyltransferase gene transcription. Annu. Rev. Nutr. 18:331-351.

Vandesompele, J., K. De Preter, F. Pattyn, B. Poppe, N. Van Roy, A. De Paepe, and F. Speleman. 2002. Accurate normalization of realtime quantitative rt-pcr data by geometric averaging of multiple internal control genes. Genome Biol. 3:research0034.

Vyas, D., U. Moallem, B. B. Teter, A. R. Fardin-Kia, and R. A. Erdman. 2013. Milk fat responses to butterfat infusion during conjugated linoleic acid-induced milk fat depression in lactating dairy cows. J. Dairy Sci. 96:2387-2399.

Yu, Y., P. H. Correll, and J. P. Vanden Heuvel. 2002. Conjugated linoleic acid decreases production of pro-inflammatory products in macrophages: Evidence for a PPAR gamma-dependent mechanism. Biochim. Biophys. Acta 1581:89-99.

Zhu, Q., G. W. Anderson, G. T. Mucha, E. J. Parks, J. K. Metkowski, and C. N. Mariash. 2005. The spot 14 protein is required for de novo lipid synthesis in the lactating mammary gland. Endocrinology 146:3343-3350. 